\title{
In Situ IR Studies on the Mechanism of Dimethyl Carbonate Synthesis from Methanol and Carbon Dioxide ${ }^{\dagger}$
}

\author{
Khalid A. Almusaiteer ${ }^{1}\left(\mathbb{D}\right.$, Sulaiman I. Al-Mayman ${ }^{2, *}{ }^{\circledR}$, Aghaddin Mamedov ${ }^{3}$ and Yousef S. Al-Zeghayer ${ }^{4}$ \\ 1 SABIC Corporate T\&I, Thuwal 23955-6900, Saudi Arabia; AlmusaiteerK@SABIC.com \\ 2 Energy and Water Research Institute, King Abdulaziz City for Science and Technology, P.O. Box 6086, \\ Riyadh 11442, Saudi Arabia \\ 3 SABIC Corporate T\&I, 1600 Industrial Blvd, Sugar Land, TX 77478, USA; amamedov@sabic.com \\ 4 Department of Chemical Engineering, King Saud University, P.O. Box 800, Riyadh 11421, Saudi Arabia; \\ yszs@ksu.edu.sa \\ * Correspondence: smayman@kacst.edu.sa \\ + This work was conducted at Riyadh College of Technology, Salahuddin District, Riyadh 12433, Saudi Arabia.
}

check for

updates

Citation: Almusaiteer, K.A.; Al-Mayman, S.I.; Mamedov, A.; Al-Zeghayer, Y.S. In Situ IR Studies on the Mechanism of Dimethyl Carbonate Synthesis from Methanol and Carbon Dioxide. Catalysts 2021, 11, 517. https://doi.org/10.3390/ catal11040517

Academic Editor: Katabathini Narasimharao

Received: 31 March 2021

Accepted: 16 April 2021

Published: 20 April 2021

Publisher's Note: MDPI stays neutral with regard to jurisdictional claims in published maps and institutional affiliations.

\section{Copyright: (C) 2021 by the authors.} Licensee MDPI, Basel, Switzerland. This article is an open access article distributed under the terms and conditions of the Creative Commons Attribution (CC BY) license (https:// creativecommons.org/licenses/by/ $4.0 /)$.

\begin{abstract}
The synthesis of dimethyl carbonate (DMC) from methanol and Carbon dioxide $\left(\mathrm{CO}_{2}\right)$ has been investigated over $5 \% \mathrm{Rh} / \mathrm{Al}_{2} \mathrm{O}_{3}$ catalyst. Diffuse Reflectance Infrared Fourier Transfer Spectroscopy (DRIFTS) was used to probe the reaction adsorbates which showed that activation of methanol and $\mathrm{CO}_{2}$ involves generation of intermediate methoxy species and formate ingredients, participating in elementary steps of DMC formation. Formation of DMC involves parallel routes comprising interaction of the $\mathrm{OH}$ group of $\mathrm{Al}_{2} \mathrm{O}_{3}$ through an acid/base mechanism and formate pathway with participation of metal sites. DMC in acid/base pathway is formed via methoxy species to form methoxy carbonate $\left(\mathrm{CH}_{3} \mathrm{O}\right) \mathrm{CO}_{2}$ (active adsorbate), which then reacts with the methyl species to form DMC. The pathway involving metal Rh sites generates an additional elementary step for the involvement of $\mathrm{CO}_{2}$ in the reaction through active formate species. The synergy of parallel pathways determines the performance of the $5 \% \mathrm{Rh} / \mathrm{Al}_{2} \mathrm{O}_{3}$ catalyst. Further improvement of catalyst performance should be based on such a feature of the reaction mechanism.
\end{abstract}

Keywords: $\mathrm{DMC} ; \mathrm{CO}_{2}$; DRIFTS; methanol; catalyst; DME

\section{Introduction}

Utilization of $\mathrm{CO}_{2}$ to form useful chemicals is one component of the urgent need to control $\mathrm{CO}_{2}$ emissions [1]. Activation and utilization of $\mathrm{CO}_{2}$ still is problematic due to the consumption of a high amount of energy for endothermic reactions of $\mathrm{CO}_{2}$ conversion to feedstock. Activation of $\mathrm{CO}_{2}$ into useful chemicals under mild, low-temperature conditions could be one of the efficient routes for $\mathrm{CO}_{2}$ utilization. Production of dimethyl carbonate (DMC) one of such route for $\mathrm{CO}_{2}$ utilization in chemical synthesis:

$$
2 \mathrm{CH}_{3} \mathrm{OH}+\mathrm{CO}_{2} \rightarrow\left(\mathrm{CH}_{3} \mathrm{O}\right)_{2} \mathrm{CO}+\mathrm{H}_{2} \mathrm{O}
$$

DMC is considered an environmentally friendly and oxygenated fuel additive (i.e., octane enhancer). Conversion of methanol with $\mathrm{CO}_{2}$ can be an alternative route for the development of an efficient technology for DMC production, which requires designing an effective catalyst composition, allowing conversion of $\mathrm{CO}_{2}$ at mild conditions.

There are multiple industrial routes to produce DMC, and the reaction of oxidative carbonylation of methanol with $\mathrm{CO}$ in the presence of oxygen is one of these most-investigated routes [2-6]. The supported $\left(\mathrm{X}\right.$ or $\mathrm{Y}$ zeolite, $\left.\mathrm{SiO}_{2}\right) \mathrm{Cu}$ catalysts are the most efficient catalysts used for this reaction. However, the catalysts applied for oxidative carbonylation undergo deactivation due to the change in particle size and sintering of metal active sites [4-6]. Besides that, oxidative carbonylation of methanol to DMC requires $\mathrm{CO}$ resources, which 
leads to additional costs for the production of DMC. The direct synthesis of DMC from methanol and $\mathrm{CO}_{2}$ is an attractive route which involves $\mathrm{CO}_{2}$ directly in the reaction and eliminates the $\mathrm{CO}$ production step [2,7-11]. The problem of the direct synthesis of DMC from methanol and $\mathrm{CO}_{2}$ is the low yield, which is due to the low rate of $\mathrm{CO}_{2}$ conversion at mild conditions.

Designing a highly active catalyst for co-conversion of methanol and $\mathrm{CO}_{2}$ at mild conditions requires understanding the principles of substrate activation to form active adsorbates (i.e., adsorbed species) and role of reaction intermediates in the reaction mechanism of DMC generation. Several proposals were suggested on mechanism of $\mathrm{CO}_{2}$ activation and its insertion to reaction intermediates, leading to DMC formation [8,12-14].

However, the corresponding literature data on reaction mechanisms are contradictory, and involve different mechanisms on the involvement of $\mathrm{CO}_{2}$ to DMC and cleavage of $\mathrm{C}-\mathrm{O}$ bonds for removal of one oxygen atom from $\mathrm{CO}_{2}$ molecules. In this paper we applied the Diffuse Reflectance Infrared Fourier Transfer Spectroscopy (DRIFTS) technique to probe the active form of adsorbates and reaction intermediates, as well as to understand the reaction mechanism in the presence of a noble-metal-based $5 \% \mathrm{Rh} / \mathrm{Al}_{2} \mathrm{O}_{3}$ catalyst. This mechanistic study will help to acquire additional information for the improvement of catalyst performance working at mild conditions.

\section{Results and Discussion}

Figure 1 shows the IR spectra of pure gaseous methanol, $\mathrm{CO}_{2}, \mathrm{DMC}$, and dimethyl ether (DME). The IR spectra show different IR features for each component, which will be used to discern the overlapping of adsorbates with gaseous species during the DMC synthesis from methanol and $\mathrm{CO}_{2}$. Figure 2 shows the IR spectra of adsorbates and gaseous species during temperature-programmed reaction (TPR) of methanol $/ \mathrm{CO}_{2}$. Flowing methanol $/ \mathrm{CO}_{2}$ at $303 \mathrm{~K}$ produces $\mathrm{C}-\mathrm{H}$ bands at 2975 and $2845 \mathrm{~cm}^{-1}$, and a $\mathrm{CO}_{2}$ band at $2350 \mathrm{~cm}^{-1}$, which were collectively similar to the pattern observed by authors of [12-21]. Increasing the temperature to $363 \mathrm{~K}$ resulted in appearance of bands at 2047 and $1926 \mathrm{~cm}^{-1}$; bands centered at 2144, 1652, and $1589 \mathrm{~cm}^{-1}$ appeared at $403 \mathrm{~K}$. The band at $1589 \mathrm{~cm}^{-1}$ can be assigned to OCO (formate), which also was observed during methanol decomposition [16] and methoxy group interaction with $\mathrm{CO}_{2}$ in the presence of Nickel acetate catalyst at supercritical conditions [18]. Appearance of bands at 2047 and $2144 \mathrm{~cm}^{-1}$ are due to the formation of adsorbed linear $\mathrm{CO}$ on reduced $\mathrm{Rh}$ sites and gaseous $\mathrm{CO}$, respectively. The band at $1652 \mathrm{~cm}^{-1}$ was assigned to the methoxy carbonate species $\left(\mathrm{CH}_{3} \mathrm{OCOO}-\mathrm{M}\right)$ similarly to the band $1623 \mathrm{~cm}^{-1}$ which was observed by authors of [20] in the presence of alumina. Authors of [21] reported that in the presence of $\mathrm{ZrO}_{2}$ catalyst, formation of methoxy carbonate species via reaction of adsorbed methoxy species and $\mathrm{CO}_{2}$ takes place more easily than that by the reaction of adsorbed $\mathrm{CO}_{2}$ with methanol. This is due to competitive adsorption of methanol and $\mathrm{CO}_{2}$ on the same sites where methanol may displace adsorbed $\mathrm{CO}_{2}$.

On the reduced $\mathrm{Rh}$ sites, activation of $\mathrm{CO}_{2}$ and its insertion to the reaction may involve some peculiarities, such as an additional pathway or mechanism which is not characteristic for $\mathrm{ZrO}_{2}$ oxide catalyst. The observed formate species suggests an existence of another pathway in addition to the common methoxy carbonate route. The formate species can be generated by the reaction of active hydrogen species, which are formed on reduced $\mathrm{Rh}$ metal sites, with the adsorbed $\mathrm{CO}_{2}$. This route probably takes place with a rate not less than that of the direct conversion of $\mathrm{CO}_{2}$ with the methoxy group into intermediate methoxy carbonate $\left(\mathrm{CH}_{3} \mathrm{OCOO}-\mathrm{M}\right)$. The decomposition of formate $\left(\mathrm{HCO}_{2}\right)$ through nonselective route leads to the formation of gaseous $\mathrm{CO}$, which was observed in Figure 2. The reverse water gas shift reaction of $\mathrm{CO}$ with $\mathrm{H}_{2} \mathrm{O}$ could be the route for restoration of $\mathrm{CO}_{2}$ concentration. Therefore, the $\mathrm{CO}_{2}$ conversion and the observed $\mathrm{CO}, \mathrm{CO}_{(\mathrm{g})}$, and $\mathrm{CO}_{2(\mathrm{~g})}$ species, in the presence of reduced $\mathrm{Rh}$ metal sites, may involve an alternative parallel formate route. Formation of $\mathrm{CO}$ during reduction of $\mathrm{CO}_{2}$ or decomposition of methanol through the formate route in the presence of different metal and oxide based catalyst is 
well described [22-25]. Bands of adsorbed methanol at 1506 and $1377 \mathrm{~cm}^{-1}$ decreased with the increase of temperature to $403 \mathrm{~K}$. The negative bands of $\mathrm{OH}$ at $3741 \mathrm{~cm}^{-1}$ and $\mathrm{H}_{2} \mathrm{O}$ at $3556 \mathrm{~cm}^{-1}$ indicate that adsorption of methanol displaced $\mathrm{H}_{2} \mathrm{O}_{a d}$ from the catalyst surface.

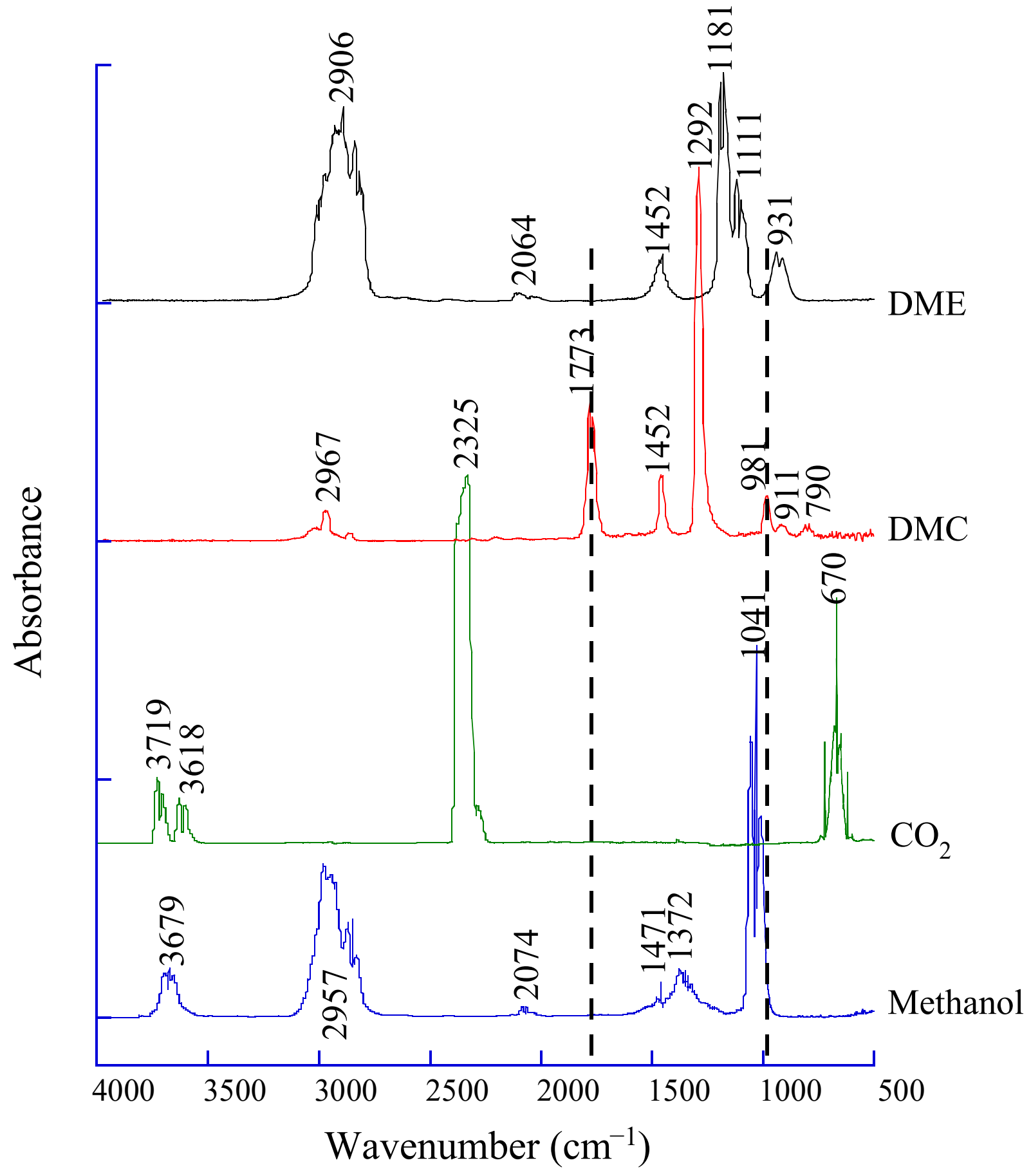

Figure 1. IR spectra of gaseous methanol, $\mathrm{CO}_{2}, \mathrm{DMC}$ and DME. 


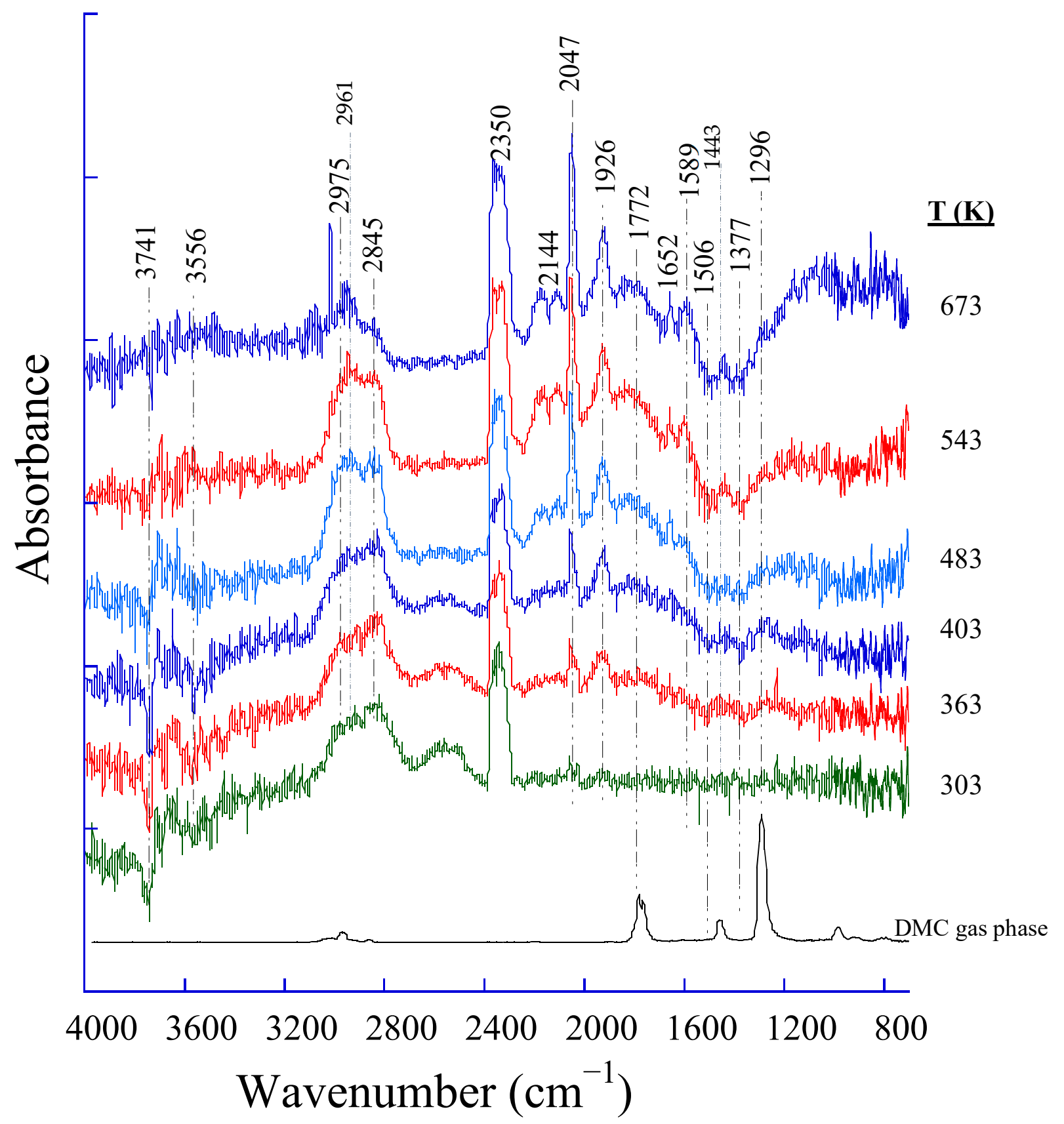

Figure 2. IR spectra during the methanol $/ \mathrm{CO}_{2}$ TPR over $\mathrm{Rh} / \mathrm{Al}_{2} \mathrm{O}_{3}$.

Figure 3 shows the MS intensity of the effluent from DRIFTS reactor cell during TPR experiments of methanol- $\mathrm{CO}_{2}$ mixture as a function of temperature. Switching the flow from He to methanol $/ \mathrm{CO}_{2}$ flow resulted in an increase in the MS intensity of methanol and $\mathrm{CO}_{2}$ to steady-state level. Increasing the temperature at $10 \mathrm{~K} / \mathrm{min}$ rate caused a decrease in the methanol MS intensity and an increase (formation) in that of DMC and $\mathrm{CO}_{2}$. The formation of DMC reaches a maximum at $541 \mathrm{~K}$. Above $541 \mathrm{~K}$, the $\mathrm{CO}_{2} \mathrm{MS}$ intensity continues to increase while those of methanol and DMC sharply decrease and level off at $673 \mathrm{~K}$. The decrease in the $\mathrm{DMC}$ formation and the increase of that of $\mathrm{CO}_{2}$ above $541 \mathrm{~K}$ may be due to the decomposition of methanol to $\mathrm{CO}_{2}$ through the reverse reaction. Reverse decomposition of methanol in the presence $\mathrm{ZnO}$ catalyst to $\mathrm{CO}_{\mathrm{x}}$ at similar reaction conditions has been previously described [23]. It was shown that methanol decomposition proceeds through intermediate methoxy intermediate. The decay in the MS intensity of $\mathrm{DMC}$ could be due to (i) shift of DMC reaction formation back in reverse direction due to 
the reaction of methanol decomposition or (ii) deactivation of the catalyst by water. The reverse reaction of methanol decomposition is an endothermic reaction and an increase of temperature shifts the reaction to the formation of carbon oxides and hydrogen without involvement of feed $\mathrm{CO}_{2}$ in the reaction. Although both factors are important, the former is more notable, due to the shift of equilibrium at high temperature within elementary steps in reverse direction. Reverse decomposition of $\mathrm{DMC}$, which formed during methanol $/ \mathrm{CO}_{2}$ TPR experiments, could also produce linear $\mathrm{CO}, \mathrm{CO}_{(\mathrm{g})}$, and $\mathrm{CO}_{2(\mathrm{~g})}$. This suggestion was provided by exposition of $\mathrm{Rh} / \mathrm{Al}_{2} \mathrm{O}_{3}$ catalyst to DMC flow at $373 \mathrm{~K}$, which produces gaseous $\mathrm{CO}_{2}$ at $2350 \mathrm{~cm}^{-1}$ and linear $\mathrm{CO}$ at $2029 \mathrm{~cm}^{-1}$ as shown in Figure 4.

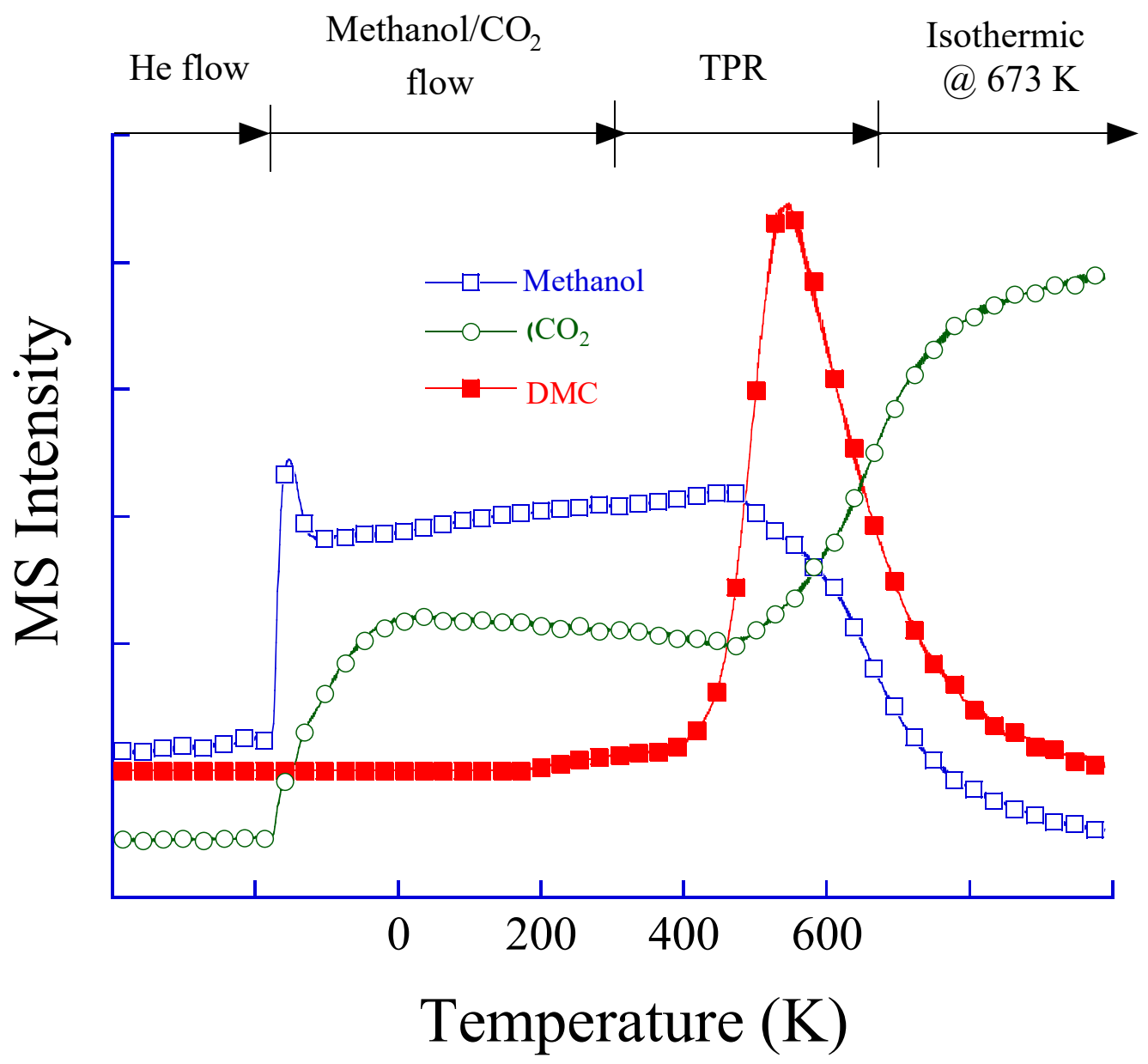

Figure 3. MS intensity during the methanol $/ \mathrm{CO}_{2} \mathrm{TPR}$ over $\mathrm{Rh} / \mathrm{Al}_{2} \mathrm{O}_{3}$.

The dynamics of IR spectra of reaction ingredients during the flow of methanol $/ \mathrm{CO}_{2}$ over $\mathrm{Rh} / \mathrm{Al}_{2} \mathrm{O}_{3}$ catalyst at $373 \mathrm{~K}$ are shown in Figure 5. The initial IR spectrum at $0.5 \mathrm{~min}$ produces bands at 1589 and $1461 \mathrm{~cm}^{-1}$. After $5 \mathrm{~min}$ of exposure to methanol/CO $\mathrm{CO}_{2}$, the intensity of the $\mathrm{C}-\mathrm{H}$ stretching bands at 2964 and $2845 \mathrm{~cm}^{-1}$ increased, together with the intensities of linear and bridge CO at 2029 and $1873 \mathrm{~cm}^{-1}$, respectively. At the same time, weak bands appeared at $1772 \mathrm{~cm}^{-1}$, which can be assigned to gaseous DMC. The observed dynamics of IR spectrum are probably due to the change of state of $\mathrm{Rh}$, particularly reduction of $R$.

In order to further elucidate the regularities of decomposition of methanol, DMC and $\mathrm{CO}_{2}$ as well as the mechanism of the $\mathrm{CO}_{\mathrm{x}}$ fragments formation, a separate experiments were carried out with flowing only methanol, $\mathrm{CO}_{2}$, or DMC at different temperatures. Figure 6 shows the IR spectra during the exposure of the catalyst to methanol at different temperatures. Linear $\mathrm{CO}$ and $\mathrm{CO}_{(\mathrm{g})}$ appear at $443 \mathrm{~K}$, and the appearance of $\mathrm{CO}_{2(\mathrm{~g})}$ started at $603 \mathrm{~K}$. Figure 7 shows the IR spectra during the exposure of the catalyst to $\mathrm{CO}_{2}$. No 
IR evidence for decomposition of $\mathrm{CO}_{2}$ as well as formation of linear $\mathrm{CO}$ and $\mathrm{CO}_{(\mathrm{g})}$ at these conditions. Therefore, in absence of hydrogen there is no dissociation of $\mathrm{CO}_{2}$ and at investigated temperatures there is no activation of $\mathrm{CO}_{2}$ with the reduced Rh sites. Absence of linear $\mathrm{CO}$ and $\mathrm{CO}_{(\mathrm{g})}$ during the catalyst exposure to $\mathrm{CO}_{2}$ flow are in agreement with the results of authors of [24] on $\mathrm{CO}_{2}$ adsorption on various catalysts. Absence of $\mathrm{CO}_{2}$ activation without adsorbed hydrogen was also previously reported during conversion of $\mathrm{CO}_{2}$ with methane [25]. The IR spectra during the exposure of the catalyst to DMC (Figure 8) shows that linear $\mathrm{CO}$ at $2029 \mathrm{~cm}^{-1}$ and $\mathrm{CO}(\mathrm{g})$ centered at $2350 \mathrm{~cm}^{-1}$ were formed at $303 \mathrm{~K}$ and continue to grow with temperature up to $673 \mathrm{~K}$. The pattern of gaseous $\mathrm{CO}$, which centered at $2136 \mathrm{~cm}^{-1}$, starts forming at $523 \mathrm{~K}$. Formation of $\mathrm{CO}$ probably proceeds through DMC decomposition to $\mathrm{CH}_{3} \mathrm{O}$ fragments, which is commonly known intermediate during the conversion of $\mathrm{CO} / \mathrm{H}_{2}$ mixture to methanol and in reverse reaction of methanol decomposition $[23,26,27]$. It was also shown that the intermediate step in methanol decomposition is formation of formaldehyde, which is the precursor of $\mathrm{CO}$ formation [23].

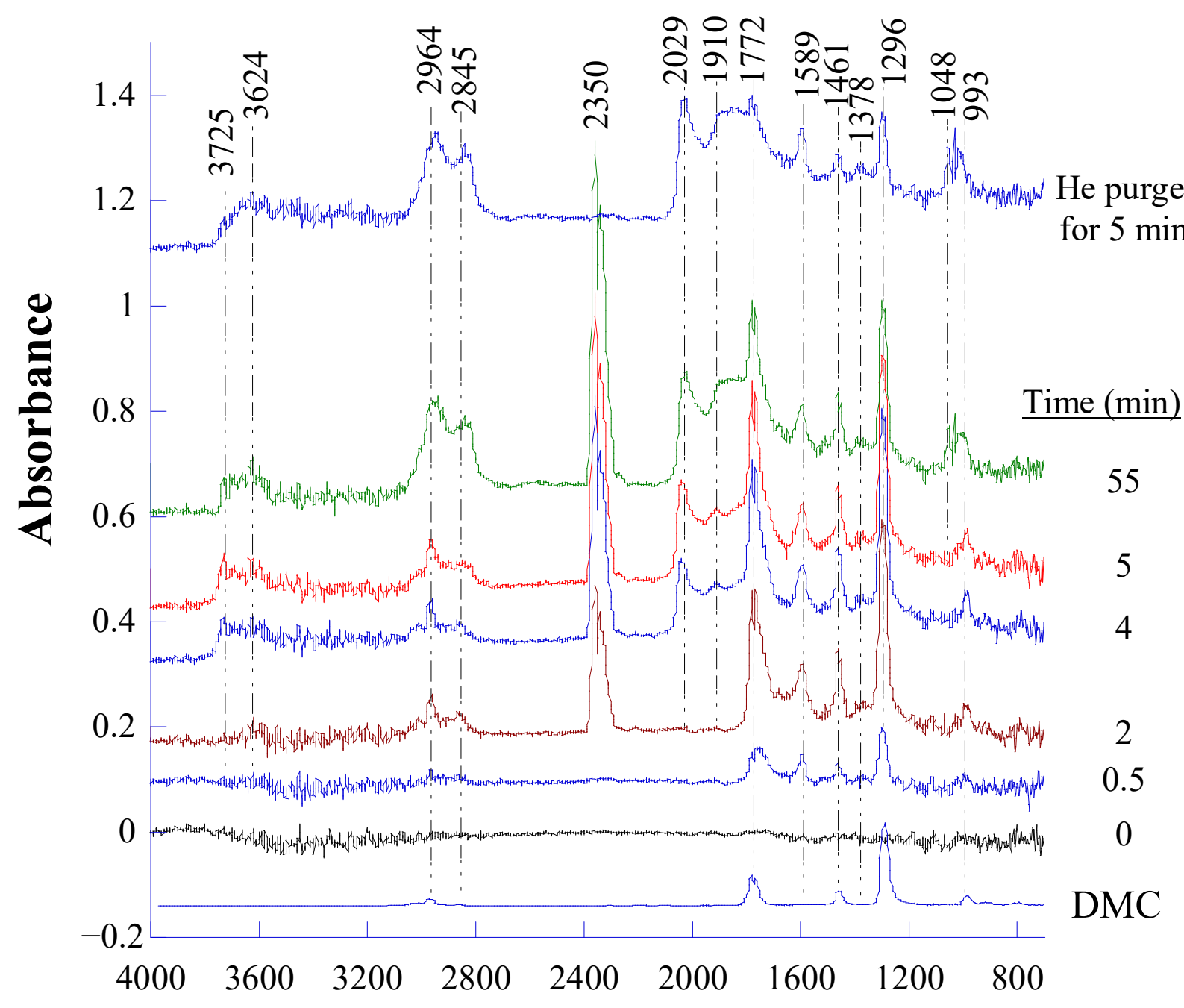

Wavenumbers $\left(\mathrm{cm}^{-1}\right)$

Figure 4. IR spectra during exposure of $5 \% \mathrm{Rh} / \mathrm{Al}_{2} \mathrm{O}_{3}$ to DMC flow at $373 \mathrm{~K}$. 




Figure 5. IR spectra during the methanol- $\mathrm{CO}_{2}$ reaction over $5 \% \mathrm{Rh} / \mathrm{Al}_{2} \mathrm{O}_{3}$ at $373 \mathrm{~K}$. 


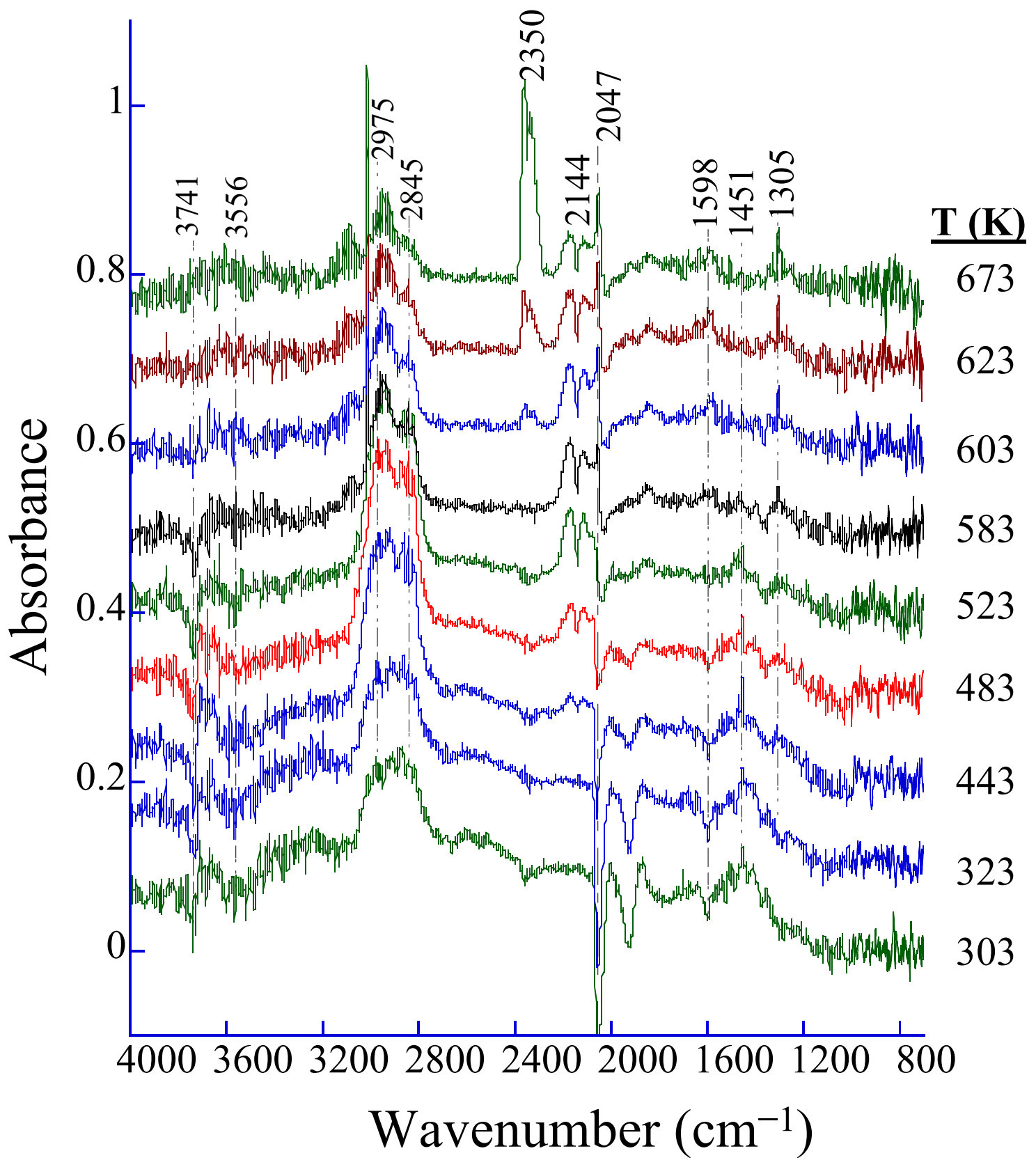

Figure 6. IR spectra during the exposure of the $\mathrm{Rh} / \mathrm{Al}_{2} \mathrm{O}_{3}$ catalyst to methanol flow at different temperatures. 


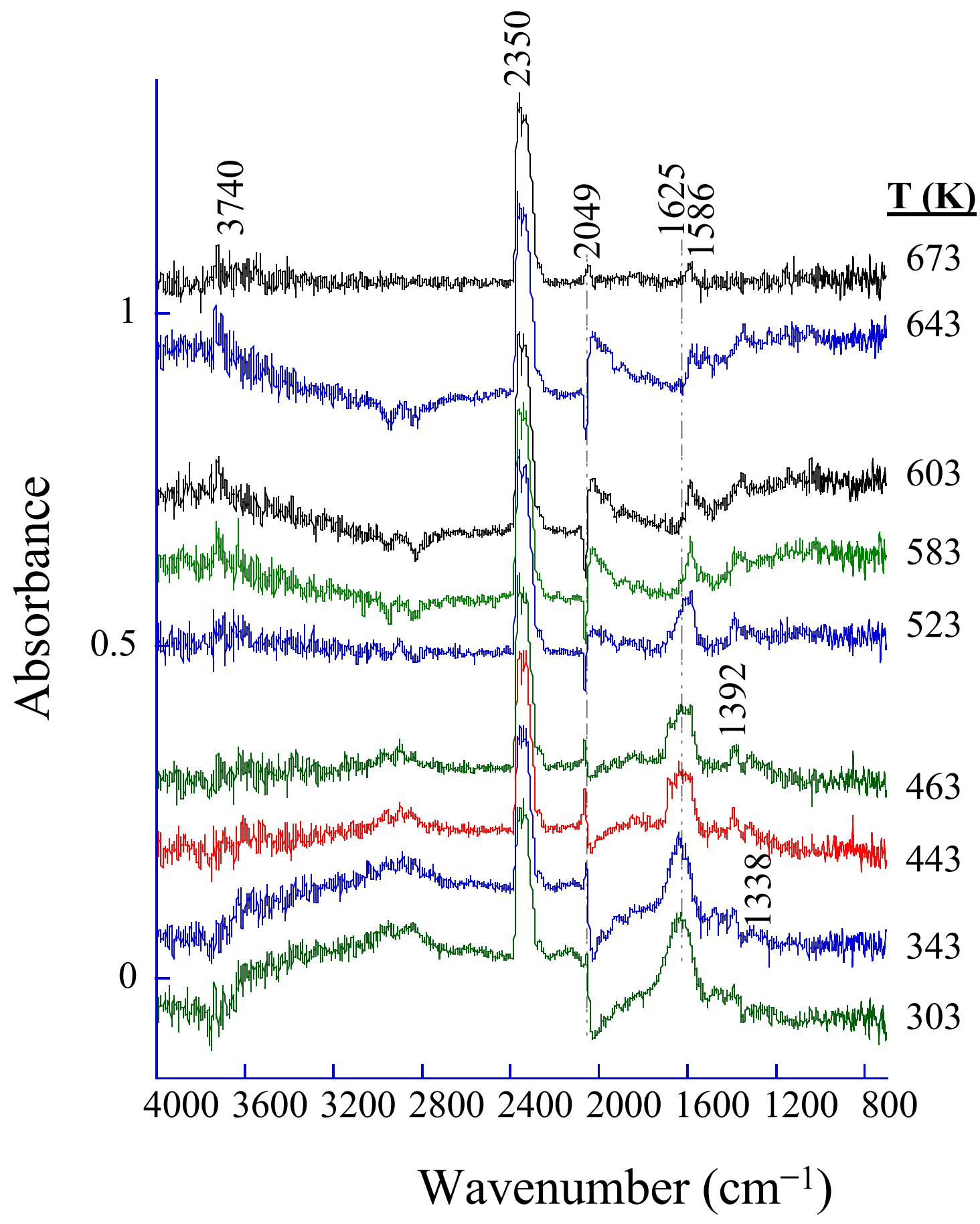

Figure 7. IR spectra during the exposure of the $\mathrm{Rh} / \mathrm{Al}_{2} \mathrm{O}_{3}$ catalyst to $\mathrm{CO}_{2}$ flow at different temperatures. 


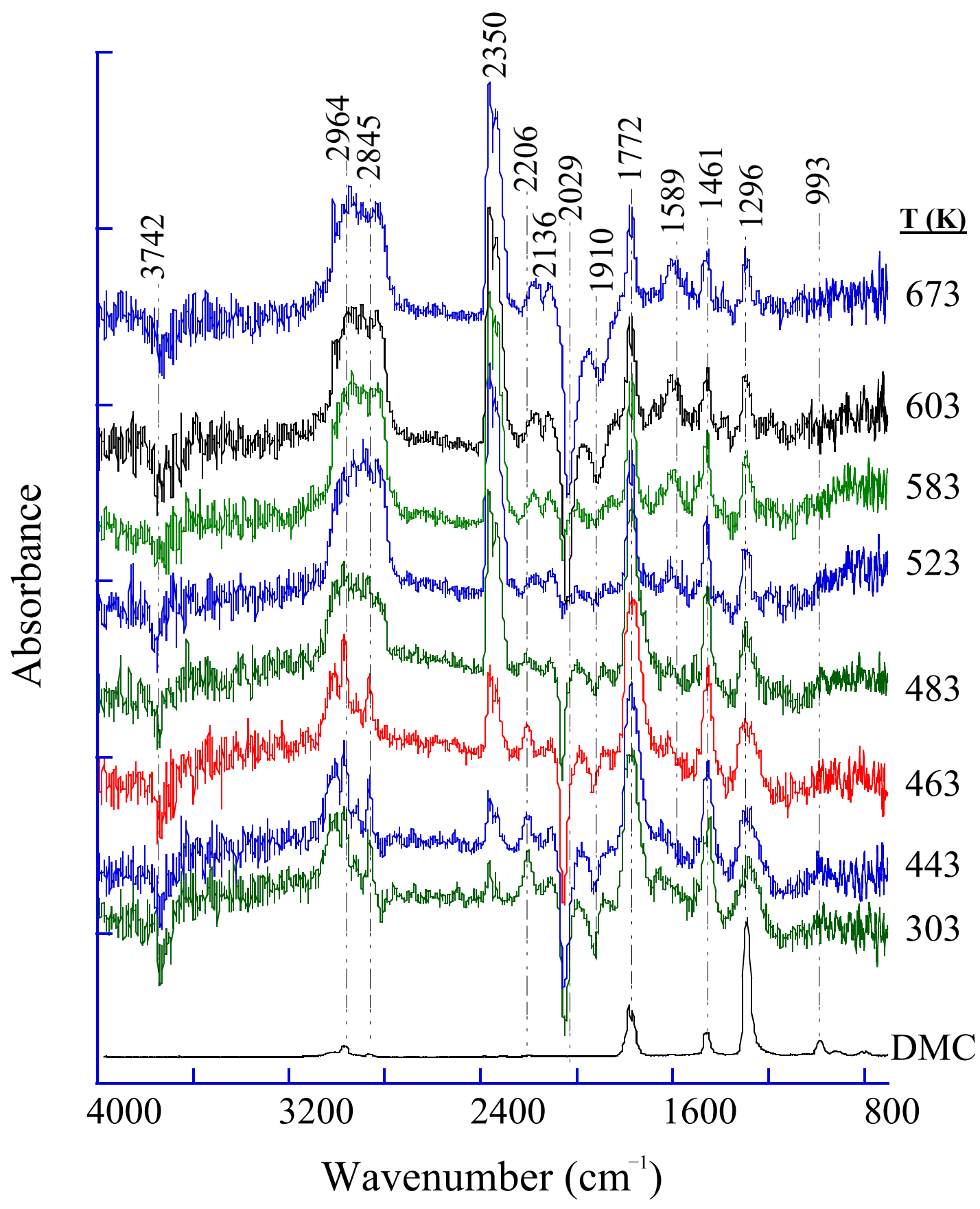

Figure 8. IR spectra during the exposure of the $\mathrm{Rh} / \mathrm{Al}_{2} \mathrm{O}_{3}$ catalyst to DMC flow at different temperatures.

It is obvious to suggest that, during decomposition of methanol, $\mathrm{CO}_{2}$ observed in the spectrum formed through $\mathrm{CO}$ oxidation to $\mathrm{CO}_{2}$, but mechanism of $\mathrm{CO}$ oxidation to $\mathrm{CO}_{2}$ is not clear because the amount of oxygen consumed for oxidation of $\mathrm{CO}$ in stoichiometric equation is not balanced. Authors of work [16] suggested that lattice oxygen of $\mathrm{ZnO}$ catalyst in some way participates in the formation of $\mathrm{CO}_{2}$. It was shown that decomposition of methanol in the presence of a $\mathrm{Cu} / \mathrm{ZrO}_{2} / \mathrm{SiO}_{2}$ catalyst proceeds through formation of adsorbed hydrogen and formate species where metallic $\mathrm{Cu}$ provides sites on which adsorbed hydrogen formed. It is necessary to note that the noble metal catalyst used in the present work has no oxygen sites and the mechanism of catalytic methanol decomposition at stationary state cannot involve oxygen from the catalyst lattice. In the presence of $\mathrm{Rh} / \mathrm{Al}_{2} \mathrm{O}_{3}$ catalyst, $\mathrm{Rh}$ site generates adsorbed hydrogen species that 
participates in the decomposition of methanol. Based on this principle, we may suggest the following mechanism of catalytic methanol decomposition:

$$
\begin{aligned}
& \mathrm{CH}_{3} \mathrm{OH}_{(\mathrm{g})} \rightarrow \mathrm{CH}_{3} \mathrm{OH}_{(\mathrm{ads})} \\
& \mathrm{CH}_{3} \mathrm{OH}_{(\mathrm{ads})} \rightarrow \mathrm{CH}_{3} \mathrm{O}_{(\text {ads })}+\mathrm{H}_{(\text {ads })} \\
& \mathrm{CH}_{3} \mathrm{O}_{(\text {ads })} \rightarrow \mathrm{CH}_{2} \mathrm{O}_{(\text {ads })}+\mathrm{H}_{(\text {ads })} \\
& \mathrm{CH}_{2} \mathrm{O}_{\text {(ads) }} \rightarrow \mathrm{CO}_{(\text {ads) }}+\mathrm{H}_{2 \text { (gas) }} \\
& \mathrm{CH}_{3} \mathrm{OH}_{(\mathrm{ads})} \rightarrow \mathrm{CH}_{3(\mathrm{ads})}+\mathrm{OH}_{(\mathrm{ads})} \\
& \mathrm{CO}_{(\text {ads })} \rightarrow \mathrm{CO}_{(\text {gas })} \\
& \mathrm{CO}_{(\mathrm{ads})}+\mathrm{OH}_{(\mathrm{ads})} \rightarrow \mathrm{HCO}_{2(\mathrm{ads})} \\
& \mathrm{HCO}_{2(\text { ads })} \rightarrow \mathrm{CO}_{2(\mathrm{ads})}+\mathrm{H}_{(\mathrm{ads})} \\
& \mathrm{CO}_{2 \text { (ads) }} \rightarrow \mathrm{CO}_{2 \text { (gas) }} \\
& \mathrm{CH}_{3(\text { ads })}+\mathrm{HCO}_{2} \rightarrow \mathrm{CH}_{3} \mathrm{O}_{(\text {ads })}+\mathrm{HCO}_{(\text {ads })} \\
& \mathrm{HCO}_{(\text {ads })} \rightarrow \mathrm{CO}_{(\mathrm{ads})}+\mathrm{H}_{(\mathrm{ads})}
\end{aligned}
$$

(ads): Indicates adsorbed species.

The adsorbed hydrogen atoms, through recombination, produce molecular hydrogen that desorbs from the surface to the gas phase. The mechanism of methanol decomposition may not be limited to the elementary steps (2 to 12 ) if the fresh catalyst involves some oxygen species. In this case, the mechanism of methanol decomposition may involve participation of lattice oxygen species, similar to the mechanism on $\mathrm{Cu}$ and $\mathrm{Zr}$ based catalysts [16]. However, at stationary condition when the oxygen is cleaned from the $\mathrm{Rh}$ sites, the reaction mechanism involves predominantly the elementary steps (2 to 12$)$. Presence of $\mathrm{CO}_{2}$ in the $\mathrm{CH}_{3} \mathrm{OH}+\mathrm{CO}_{2}$ mixture facilitate the formation of formate fragments $\mathrm{HCOO}_{2}$, which becomes an additional important step as precursor for DMC formation.

The most important step in the stepwise mechanism (2-12) is the decomposition of methanol to $\mathrm{CH}_{3}$ fragments and $\mathrm{OH}$ group (step 6). It is probable that this step has the lowest rate among other steps. It is necessary to note that the similar decomposition of methanol was suggested by authors of work [16] who suggested that "methanol should be activated to adsorbed $\mathrm{CH}_{3}{ }^{+}$and adsorbed $\mathrm{OH}$ - on the neighboring acid sites." The authors also mentioned that this step may be the rate-determining step in DMC formation.

The reaction steps (2-12) describe the decomposition of methanol in the absence of $\mathrm{CO}_{2}$ in the gas. However, the mechanism of methanol conversion by $\mathrm{CO}_{2}$ in the presence of Lewis basic sites of Rh and acidic site of Al-O frame may have its special features while, in this case, formation of DMC could involve parallel pathways. It is clear that the role of each route in DMC formation will be determined with the rate of methanol decomposition in direction of cleavage of $\mathrm{O}-\mathrm{H}$ and $\mathrm{C}-\mathrm{O}$ bonds.

\section{Mechanism of DMC Formation}

Figure 9 shows the IR spectra generated during methanol- $\mathrm{CO}_{2}$ reaction over $5 \%$ $\mathrm{Rh} / \mathrm{Al}_{2} \mathrm{O}_{3}$ catalyst at $393 \mathrm{~K}$. The IR spectrum of gaseous DMC was included to elucidate the DMC formation. Introduction of methanol- $\mathrm{CO}_{2}(2: 1)$ resulted in appearance of gaseous methanol centered at $2888,2061,1036 \mathrm{~cm}^{-1}$ and $\mathrm{CO}_{2}$ centered at $2345 \mathrm{~cm}^{-1}$. After $3 \mathrm{~min}$, new band at $1742 \mathrm{~cm}^{-1}$ was observed due to gaseous DMC and 1596 and 1484, $1458 \mathrm{~cm}^{-1}$ due to methoxy carbonate species. The intensity of the $1742 \mathrm{~cm}^{-1}$ increased with time and reached maximum after $21 \mathrm{~min}$. The decrease in the IR intensity of the $1742 \mathrm{~cm}^{-1}$ band was accompanied by emergence of gaseous CO band centered at $2138 \mathrm{~cm}^{-1}$ and an increase in the IR intensity of methoxy carbonate species at $1458 \mathrm{~cm}^{-1}$. 


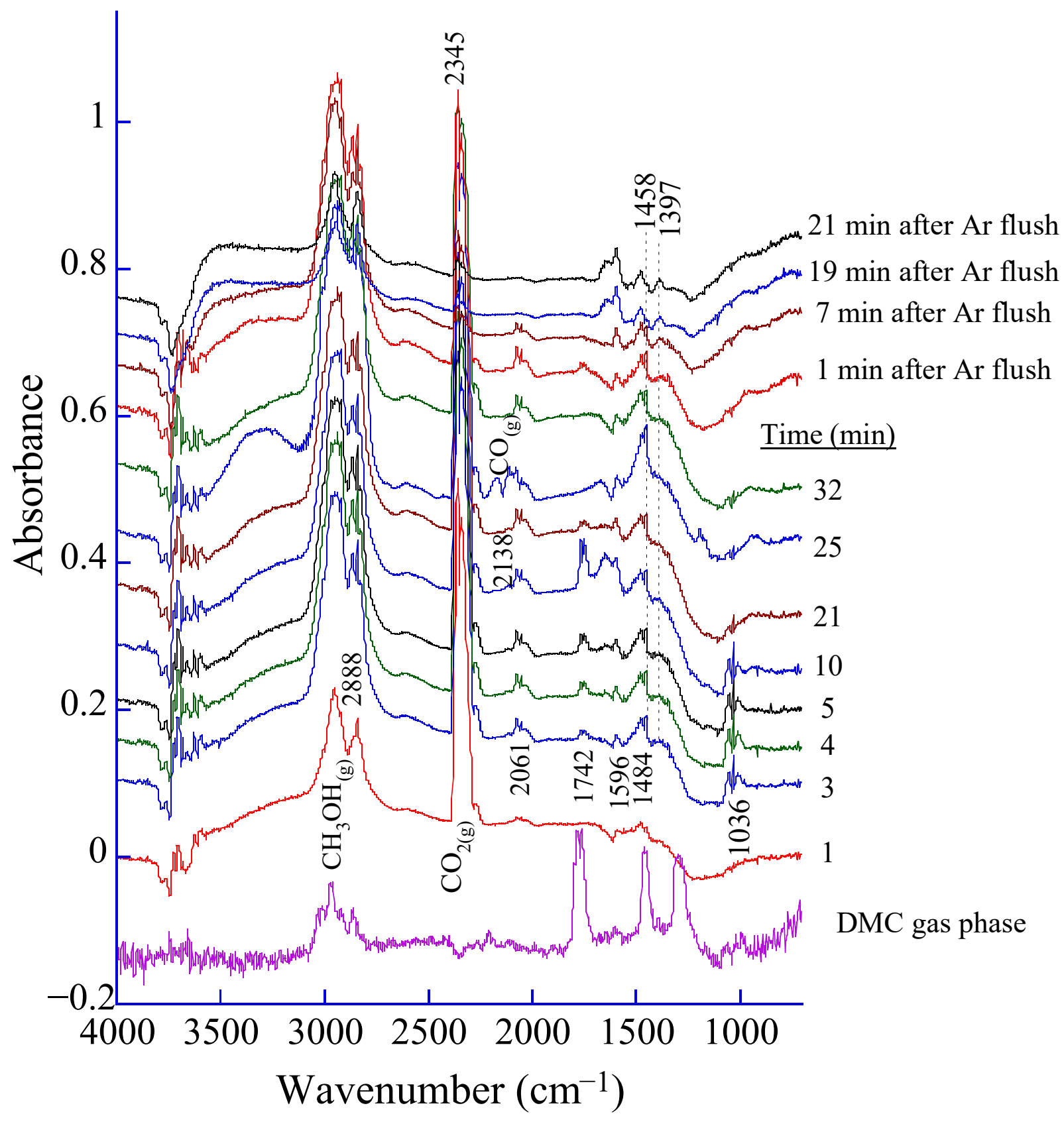

Figure 9. IR spectra during the methanol- $\mathrm{CO}_{2}$ reaction over $5 \% \mathrm{Rh} / \mathrm{Al}_{2} \mathrm{O}_{3}$ at $393 \mathrm{~K}$.

The reaction mechanism of DMC production from methanol and $\mathrm{CO}_{2}$ has been described by many authors [12-14,17-19,28-30]. The mechanism of DMC production from methanol and $\mathrm{CO}_{2}$ usually involves participation of large amount of $\mathrm{OH}$ groups and formation of bidentate carbonate species. In most cases the mechanism of DMC synthesis has been described for $\mathrm{ZrO}_{2}, \mathrm{CeO}_{2}$ and $\mathrm{CeO}_{2}-\mathrm{ZrO}_{2}$ based catalysts. It was reported that in the presence of $\mathrm{ZrO}_{2}$ catalyst the neighboring acid-base sites both are responsible for activity of the catalyst for production of dimethyl carbonate [28]. The following mechanism was suggested to describe DMC production [21]:

$$
\begin{gathered}
\mathrm{CH}_{3} \mathrm{OH}+(\text { Basic site }) \rightarrow \mathrm{CH}_{3} \mathrm{O}^{-}{ }_{\text {(ads) }}+\mathrm{H}^{+}{ }_{\text {(ads) }} \\
\mathrm{CO}_{2}+(\text { Basic site }) \rightarrow \mathrm{CO}_{2} \text { (ads) } \\
\mathrm{CH}_{3} \mathrm{O}^{-}{ }_{\text {(ads) }}+\mathrm{CO}_{2} \text { (ads) }+\left(\text { Basic site) } \rightarrow \mathrm{CH}_{3} \mathrm{OCO}_{2}{ }^{-}\right. \text {(ads) }
\end{gathered}
$$




$$
\begin{gathered}
\mathrm{CH}_{3} \mathrm{OH}+\text { (acidic site) } \rightarrow \mathrm{CH}_{3}{ }^{+}{ }_{\text {ads })}+\mathrm{OH}^{-}{ }_{\text {(ads) }} \\
\mathrm{CH}_{3} \mathrm{OCO}_{2}{ }^{-}{ }_{\text {(ads) }}+\mathrm{CH}_{3}{ }^{+}{ }_{\text {(ads) }} \rightarrow\left(\mathrm{CH}_{3} \mathrm{O}\right)_{2} \mathrm{CO} \\
\mathrm{H}^{+}{ }_{\text {(ads) }}+\mathrm{OH}^{-}{ }_{\text {(ads) }} \rightarrow \mathrm{H}_{2} \mathrm{O}
\end{gathered}
$$

It was suggested that the initial adsorption of $\mathrm{CH}_{3} \mathrm{OH}$ on a catalyst surface occurs via the interaction of the $\mathrm{O}$ atom of $\mathrm{CH}_{3} \mathrm{OH}$ with a coordinately unsaturated Lewis acid center on the surface with the formation of methoxy species. Abstraction of hydrogen by surface Lewis base sites has been suggested by [29] as well. For closing of the water formation cycle, the surface hydrogen protons undergo the acid-base interaction with the surface hydroxyl group (step 18). However, steps (13-18) involve only the methanol decomposition without the step for formation of adsorbed methanol species.

In accordance with the reaction steps (13-18), formation of DMC takes place via reaction of adsorbed $\mathrm{CO}_{2}$ with methoxy species to form methoxy carbonate (reaction 15), which then reacts with methyl species (reaction 17). Results from X-ray absorption fine structure (XAFS) spectra suggested that $\mathrm{CO}_{2}$ during reaction with methanol in the presence of $\mathrm{Cu}-\mathrm{CeO}_{2}$ catalyst undergoes reduction with the realization of redox reaction cycle with standard spectrum component of $\mathrm{Ce}^{4+}$ and $\mathrm{Ce}^{3+}$ was 90 and $10 \%$, respectively [30]. The content of reduced $\mathrm{Ce}^{3+}$ sites $(10 \%)$ associated with the surface $\mathrm{O}$ vacancy decreased to $5 \%$ under $\mathrm{CO}_{2}$ at $290 \mathrm{~K}$ for reduced $\mathrm{Cu}-\mathrm{CeO}_{2}$ catalyst. However, the reaction mechanism, proposed by authors, does not involve regeneration of reduced sites by $\mathrm{CO}_{2}$, which will lead to $\mathrm{CO}$ generation. The $\mathrm{CeO}_{2}$ component of the catalyst plays the role of an electrondonating Lewis site. The authors did not, however, show any $\mathrm{CO}$ spectrum or suggestions on a mechanism for insertion of $\mathrm{CO}$ to methanol molecules to form DMC.

Our earlier studies [15] showed that absence of $\mathrm{CO}$ participation in intermediate stages of DMC formation when the $\mathrm{CO}_{2}$ in a $\mathrm{CH}_{3} \mathrm{OH}-\mathrm{CO}_{2}$ mixture was replaced by $\mathrm{CO}$. Therefore, formation of DMC through insertion of adsorbed $\mathrm{CO}$ into two methoxy species does not occur. The insertion of $\mathrm{CO}_{2}$ into a $\mathrm{M}-\mathrm{OCH}_{3}$ bond without dissociation to $\mathrm{CO}$ (reaction 15) is confirmed by the low conversion of $\mathrm{CO}_{2}$ during its decomposition [15] and was also reported in [19] for $\mathrm{Cu}-\mathrm{Ni}$ based catalytic systems. IR results showed that there was a large amount of basic sites that participated in activation of methanol to methoxy species and their subsequent reaction with the activated carbon dioxide.

Authors of work [29] also suggested that adsorption of $\mathrm{CO}_{2}$ might be the key step in DMC synthesis. It was shown that abstraction of hydrogen from methanol takes place at the neighboring sites of adsorbed $\mathrm{CO}_{2}$. Two methoxy groups and an adsorbed $\mathrm{CO}_{2}$ combined together to form DMC and water, which followed by catalyst re-oxidation to restore surface oxygen vacancy.

Unnikrishnan and Darbha [30] suggested a different mechanism for DMC synthesis in the presence of $\mathrm{CeO}_{2}$ catalyst. Based on their mechanism, methanol on the surface first generates $\mathrm{OH}$ group, which in the subsequent step through the reaction with methanol generates methoxy groups. By the authors' opinion, conversion of methanol and DMC correlates with the concentration of both acidic and basic sites. Reaction of methoxy group with adsorbed $\mathrm{CO}_{2}$, similar to step (15), leads to the formation of $\mathrm{CH}_{3} \mathrm{OCO}_{2}$ fragments, which then reacts with methanol to form DMC.

The mechanism of DMC formation in the presence of a $\mathrm{ZrO}_{2}$ catalyst proposed by $[28,31-33]$ is different from that was suggested by $[29,30]$ for $\mathrm{CeO}_{2}, \mathrm{Cu}-\mathrm{CeO}_{2}$ and $\mathrm{Ni}-\mathrm{Cu}$ type catalysts. Using IR spectroscopy, it was shown that the change of oxidation state of $\mathrm{Zr}$ in zirconium oxide lead to a significant change in the mechanism of DMC and rate of elementary steps [31,32]. In the presence of $\mathrm{ZrO}_{2}$ phase $\mathrm{CH}_{3}$ insertion to methyl carbonate was twice as fast as that of $\mathrm{CO}_{2}$ insertion to methyl carbonate. Author suggested that both routes take place with the participation of Brønsted basicity of hydroxyl groups and $\mathrm{Zr}^{4+} \mathrm{O}^{2-}$ Lewis acid/base pairs existed on the surface of zirconia.

It is necessary to note that the acid-base features of $\mathrm{Rh} / \mathrm{Al}_{2} \mathrm{O}_{3}$ catalyst are different from the catalysts, discussed above in [29-33]. During the reaction at stationary conditions the noble metal Rh has different surface properties and therefore activation of methanol 
substrate may not involve $\mathrm{OH}$ group as an initial active site for abstraction of hydrogen from methanol.

We propose abstraction of hydrogen from methanol by reduced Rh atoms with formation of adsorbed hydrogen species, (step 19), below where the reduced Rh sites plays the role of Lewis bases. These active sites presented in the form of **:

$$
\begin{aligned}
\mathrm{CH}_{3} \mathrm{OH}+2^{* *} \rightarrow \mathrm{CH}_{3} \mathrm{O}_{(\mathrm{ads})}+\mathrm{H}_{(\mathrm{ads})} \\
\mathrm{H}_{(\mathrm{ads})}+\mathrm{CO}_{2} \rightarrow \mathrm{HCO}_{2(\mathrm{ads})} \\
\mathrm{HCO}_{2(\mathrm{ads})} \leftrightarrow \mathrm{HOCO}_{(\mathrm{ads})} \\
\mathrm{CH}_{3} \mathrm{OH}+{ }^{* *} \leftrightarrow \mathrm{CH}_{3} \mathrm{OH}_{(\mathrm{ads})} \\
\mathrm{CH}_{3} \mathrm{OH}_{(\mathrm{ads})}+\mathrm{HCO}_{2(\mathrm{ads})} \leftrightarrow \mathrm{CH}_{3} \mathrm{OCO}_{(\mathrm{ads})}+\mathrm{H}_{2} \mathrm{O} \\
\mathrm{CH}_{3} \mathrm{O}_{(\mathrm{ads})}+\mathrm{CH}_{3} \mathrm{OCO}_{(\mathrm{ads})} \rightarrow \mathrm{CH}_{3} \mathrm{OCOCH}_{3} \mathrm{O}(\mathrm{DMC})
\end{aligned}
$$

The suggested mechanism (steps 19-24) is the parallel pathway for DMC production that takes place with participation of a non-oxide based Rh catalyst. The suggested parallel way of DMC formation does not exclude the reaction mechanism (steps 13-18), which may takes place by the participation of $\mathrm{Al}_{2} \mathrm{O}_{3}$ acidic support of an $\mathrm{Rh} / \mathrm{Al}_{2} \mathrm{O}_{3}$ catalyst. Step 19 describes the heterolytic dissociation of methanol with the formation of $\mathrm{H}_{(\mathrm{ads})}$ and $\mathrm{CH}_{3} \mathrm{O}_{(\text {ads }}$ fragments. It is reasonable to suggest that $\mathrm{H}_{(\text {ads })}$ fragments may be generated with participation of Al-O group of acidic support while the $\mathrm{CH}_{3} \mathrm{O}_{(\mathrm{ads})}$ ingredient describes $\mathrm{Me}-\mathrm{OCH}_{3}$ intermediates formed with involvement of Lewis basic sites.

The reaction mechanism of DMC formation considers conjugation of two parallel pathways of its formation. The cross-linking of these parallel pathways may proceed through formation of intermediate DME. In this case the stepwise mechanism (19-24) should include formation of DME as an intermediate ingredient. The DME formation, in contrast to DMC, favors a high temperature and low $\mathrm{CO}_{2}$ pressure [33]. The DME gas phase product was not observed in IR spectra but bands at 2961 and $2845 \mathrm{~cm}^{-1}$ in Figure 2 can be assigned to molecularly adsorbed DME [34]. The formation of DME was reported at $>400 \mathrm{~K}$ in our earlier studies [15], which were carried out by feeding a mixture of methanol and $\mathrm{CO}_{2}$ through a plug flow reactor. These studies showed that DMC synthesis proceeded effectively at low temperatures (353-433 K), while at higher temperatures DME became the predominant product. It is probable that, at low temperatures, DME was produced as an intermediate product, participating in consecutive steps of DMC generation while at high temperatures DME desorbed from the surface and showed up in the gas phase.

Adsorption of methanol on two acid sites may generate intermediate DME, which reacts very fast with the $\mathrm{HCO}_{2(\mathrm{ads})}$ :

$$
\begin{gathered}
2 \mathrm{CH}_{3} \mathrm{OH}+2\left({ }^{* *}\right)_{\text {acid }} \rightarrow \mathrm{CH}_{3} \mathrm{OCH}_{3(\text { ads })}+\mathrm{H}_{2} \mathrm{O}_{(\text {ads })} \\
\mathrm{CH}_{3} \mathrm{OCH}_{3(\text { ads })}+\mathrm{HCO}_{2(\text { ads })} \rightarrow \mathrm{CH}_{3} \mathrm{OCO}_{(\text {ads })}+\mathrm{CH}_{3} \mathrm{OH}_{(\text {ads })}
\end{gathered}
$$

The elementary step (26) may present conjugation of reaction pathways, carried with participation of Lewis base and Al-O group of acidic support. Combination of elementary steps (25) and (26) gives the elementary step (23). The surface methoxy fragments, generated within two pathways, are the main intermediates for synthesis of DMC. Combination of strong Lewis basic sites and acid centers of $\mathrm{Al}-\mathrm{O}$ frame of support are necessary to increase the rate of methoxy fragment generation within conjugated elementary steps. The direction of the reaction via elementary steps (19-26) with participation of Rh sites is the predominant route in comparison with the decomposition of methanol to $\mathrm{CH}_{3(\mathrm{ads})}$ and $\mathrm{OH}_{(\mathrm{ads})}$ fragments on acid site. 


\section{Experimental}

The $5 \mathrm{wt} \% \mathrm{Rh}$ catalyst was prepared by incipient wetness impregnation of $\mathrm{RhCl}_{3} \cdot 2 \mathrm{H}_{2} \mathrm{O}$ (Alfa Chemicals) on $\mathrm{Al}_{2} \mathrm{O}_{3}$ (Degussa: $100 \mathrm{~m}^{2} / \mathrm{g}$ ). The catalyst was dried overnight in air at room temperature, calcined by flowing air at $523 \mathrm{~K}$ for $30 \mathrm{~min}$ and subsequently reduced by flowing $\mathrm{H}_{2}$ at $673 \mathrm{~K}$ for $1 \mathrm{~h}$.

The reactor system used in this work is described elsewhere [15]. Scheme 1 shows the experimental system, which consists of a gas flow section with a 4-port switching valve, a DRIFTS cell with catalyst, a tubular reactor with catalyst and mass spectrometer (MS) (Pfeiffer Vacuum GmbH, Berliner Str. 43, 35614 Aßlar, Germany). The adsorption intensity and vibrational frequency (wavenumber, $\mathrm{cm}^{-1}$ ) of adsorbed and gaseous species on the catalyst surface were measured by IR spectrometer. The effluent concentrations of gaseous reactants/products were measured by MS. The flow rates of the gasses were controlled by mass flow controllers (Omega 750). The heating rate during the Temperature-Programmed Reaction (TPR) studies was $10 \mathrm{~K} / \mathrm{min}$ and the methanol: CO ratio was (2:1).

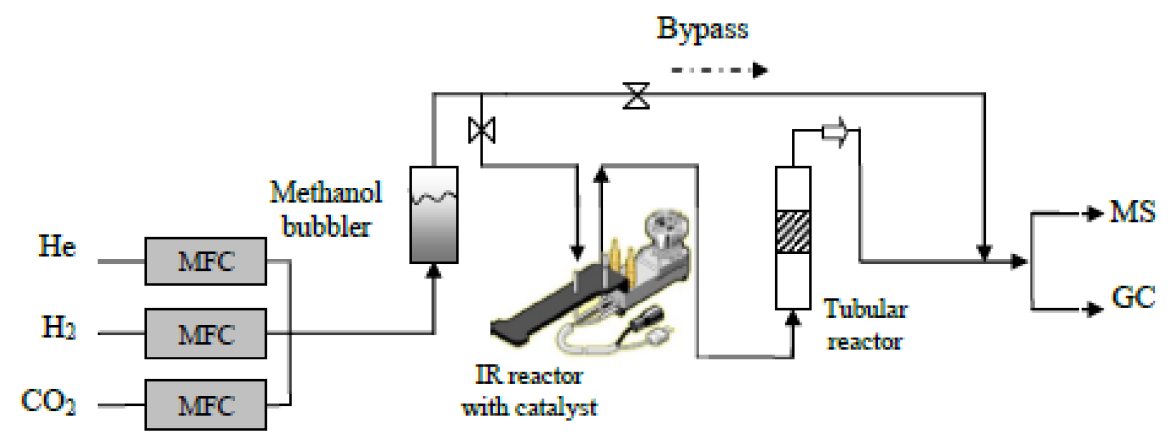

MFC : Mass Flow Controller

प: Particles Filter

Scheme 1. The experimental system for TPR studies.

The IR spectra were collected by a Thermo Nicolet Nexus 670 FTIR spectrometer (Thermo Electron North America, USA) equipped with a MCT detector that was cooled with liquid nitrogen. A high pressure/high temperature chamber fitted with ZnSe windows was utilized as an IR reactor cell for in situ reaction studies. The IR reactor cell was heated by temperature controller. The lines from the methanol bubbler to the IR cell, GC and MS were warped with heating tape and insulated with general purpose insulating wrap. For steady-state spectra, 64 scans are co-added at a resolution of $4 \mathrm{~cm}^{-1}$. Co-adding a large number of scans increases the signal to noise ratio $(\mathrm{S} / \mathrm{N})$, but requires a longer sampling time, resulting in the loss of the transient information.

\section{Conclusions}

In this work, the peculiarities of direct synthesis $\mathrm{DMC}$ from methanol and $\mathrm{CO}_{2}$ has been studied over a $5 \% \mathrm{Rh} / \mathrm{Al}_{2} \mathrm{O}_{3}$ catalyst using a combination of a vapor phase flow reactor system and the Diffuse Reflectance Infrared Fourier Transfer Spectroscopy (DRIFTS) technique coupled with Temperature-Programmed Reaction (TPR) to probe adsorbates and reaction intermediates. It has been established that methanol undergoes decomposition with the generation of methoxy species, which then reacts with $\mathrm{CO}_{2}$ through formate species. The intermediate methoxy species and the chemosorbed and formate forms of $\mathrm{CO}_{2}$ play an important role in the DMC synthesis, and the participation of two parallel pathways take place in DMC formation. Formation of DME involves parallel routes comprising interactions of the $\mathrm{OH}$ group of $\mathrm{Al}_{2} \mathrm{O}_{3}$ through the acid/base mechanism and formate pathway with participation of metal sites. The pathway involving metal sites generates an additional elementary step for involvement of $\mathrm{CO}_{2}$ to the reaction through 
active formate species. The synergy of parallel pathways determines the performance of the $5 \% \mathrm{Rh} / \mathrm{Al}_{2} \mathrm{O}_{3}$ catalyst. Therefore, selection of the catalyst and improvement of its performance should be based on such a feature of the reaction mechanism. Promotion of Rh with additional metal may increase the rate of formate route while acid-base performance of catalyst can be enhanced by the addition of oxides, such $\mathrm{ZrO}_{2}$ or $\mathrm{CeO}_{2}$, suggested by authors of $[31,32]$. The effectiveness of $\mathrm{Rh} / \mathrm{Al}_{2} \mathrm{O}_{3}$ catalyst, for DMC synthesis, is attributed to the presence of two pathways comprising Lewis basic sites of metallic $\mathrm{Rh}$ and $\mathrm{OH}$ groups, generated on $\mathrm{Al}_{2} \mathrm{O}_{3}$. The Lewis basic sites are needed for abstraction of hydrogen from methanol, which initiates the formate pathway of DMC generation. The acid-base route of support participates to supply methyl groups from methanol to the methyl route of the reaction mechanism.

Author Contributions: The following is a specific contribution of each author into this manuscript: Conceptualization: K.A.A. and S.I.A.-M. Methodology, K.A.A. and S.I.A.-M. Validation: K.A.A., S.I.A.M. and A.M.; Formal analysis: K.A.A. and A.M.; Investigation: K.A.A., S.I.A.-M., A.M. and Y.S.A.-Z.; Data curation: Y.S.A.-Z.; Writing—original draft preparation: K.A.A., S.I.A.-M. and A.M.; Writingreview and editing: K.A.A., S.I.A.-M., A.M. and Y.S.A.-Z.; Visualization: K.A.A.; Supervision: S.I.A.-M.; Project administration: K.A.A.; Funding acquisition: K.A.A. and S.I.A.-M. All authors have read and agreed to the published version of the manuscript.

Funding: This research received no external funding.

Data Availability Statement: The data presented in this study are openly available online.

Acknowledgments: We highly appreciate the financial support by King Abdulaziz City for Science and Technology under Grant (AT-21-73).

Conflicts of Interest: The authors declare no conflict of interest.

\section{References}

1. Liu, Q.; Wu, L.; Jackstell, R.; Beller, M. Using carbon dioxide as a building block in organic synthesis. Nat. Commun. 2015, 6, 5933. [CrossRef] [PubMed]

2. Liu, B.; Li, C.; Zhang, G.; Yan, L.; Li, Z. Direct synthesis of dimethyl carbonate from $\mathrm{CO}_{2}$ and methanol over $\mathrm{CaO}_{-} \mathrm{CeO} 2$ catalysts: The role of acid-base properties and surface oxygen vacancies. New J. Chem. 2017, 41, 12231-12240. [CrossRef]

3. Santos, B.A.V.; Silva, V.M.T.M.; Loureiro, J.M.; Rodrigues, A.E. Review for the Direct Synthesis of Dimethyl Carbonate. ChemBioEng Rev. 2014, 1, 214-229. [CrossRef]

4. Sato, Y.; Kagotani, M.; Yamamoto, T.; Souma, Y. Novel effective poly (2,2'-bipyridine-5,5'-diyl)-CuCl 2 catalyst for synthesis of dimethyl carbonate (DMC) by oxidative carbonylation of methanol. Appl. Catal. A 1999, 2, 219-226. [CrossRef]

5. Ono, Y. Dimethyl carbonate for environmentally benign reactions. Pure Appl. Chem. 1996, 68, 367-375. [CrossRef]

6. King, S.T. Reaction Mechanism of Oxidative Carbonylation of Methanol to Dimethyl Carbonate in Cu-Y Zeolite. J. Catal. 1996, 2, 530-538. [CrossRef]

7. Zhaofu, Z.; Shuaishuai, L.; Lujun, Z.; Shuai, Y.; Guanying, Y.; Buxing, H. Driving dimethyl carbonate synthesis from $\mathrm{CO}_{2}$ and methanol and production of acetylene simultaneously using $\mathrm{CaC}_{2}$. Chem. Commun. 2018, 54, 4410-4412.

8. Shu-Yang, Z.; Sheng-Ping, W.; Yu-Jun, Z.; Xin-Bin, M. An in situ infrared study of dimethyl carbonate synthesis from carbon dioxide and methanol over well-shaped $\mathrm{CeO}_{2}$. Chin. Chem. Lett. 2017, 28, 65-69.

9. Pacheco, M.A.; Marshall, C.L. Review of Dimethyl Carbonate (DMC) Manufacture and its Characteristics as a Fuel Additive. Energ. Fuels 1997, 11, 2-29. [CrossRef]

10. Meng, Z.; Yonghang, X.; Brandon, L.W.; Min, X.; Shuanjin, W.; Dongmei, H.; Luyi, S.; Yuezhong, M. Catalytic materials for direct synthesis of dimethyl carbonate (DMC) from $\mathrm{CO}_{2}$. J. Clean. Prod. 2021, 279, 123344.

11. Romano, U.; Tesel, R.; Mauri, M.M.; Rebora, P. Synthesis of Dimethyl Carbonate from Methanol, Carbon Monoxide and Oxygen Catalyzed by Copper Compounds. Ind. Eng. Chem. Prod. Res. Dev. 1980, 19, 396-403. [CrossRef]

12. Marin, C.M.; Li, L.; Bhalkikar, A.; Doyle, J.E.; Zeng, X.C.; Cheung, C.L. Kinetic and mechanistic investigations of the direct synthesis of dimethyl carbonate from carbon dioxide over ceria nanorod catalysts. J. Catal. 2016, 340, 295-301. [CrossRef]

13. Hofmann, H.J.; Brandner, A.; Claus, P. Direct Synthesis of Dimethyl Carbonate by Carboxylation of Methanol on Ceria-Based Mixed Oxides. Chem. Eng. Technol. 2012, 35, 2140-2146. [CrossRef]

14. Lee, H.J.; Park, S.; Song, I.K.; Jung, J.C. Direct Synthesis of Dimethyl Carbonate from Methanol and Carbon Dioxide over $\mathrm{Ga}_{2} \mathrm{O}_{3} / \mathrm{Ce} 0.6 \mathrm{Zr0} 0.4 \mathrm{O} 2$ Catalysts: Effect of Acidity and Basicity of the Catalysts. Catal. Lett. 2011, 141, 531-537. [CrossRef]

15. Almusaiteer, K. Synthesis of dimethyl carbonate (DMC) from methanol and $\mathrm{CO}_{2}$ over Rh-supported catalysts. Catal. Commun . 2009, 10, 1127-1131. [CrossRef] 
16. Fisher, I.A.; Bell, A.T. A Mechanistic Study of Methanol Decomposition over Cu/SiO $2, \mathrm{ZrO}_{2} / \mathrm{SiO}_{2}$, and Cu/ $\mathrm{ZrO} 2 / \mathrm{SiO}$. J. Catal. 1999, 184, 357-376. [CrossRef]

17. Zhao, T.; Han, Y.; Sun, Y. Novel reaction route for dimethyl carbonate synthesis from $\mathrm{CO}_{2}$ and methanol. Fuel Process. Technol. 2000, 62, 187-194. [CrossRef]

18. Zhao, T.; Han, Y.; Sun, Y. Supercritical synthesis of dimethyl carbonate from $\mathrm{CO}_{2}$ and methanol. Stud. Surf. Sci. Catal. 2000, 130, 461-466.

19. Wu, X.; Meng, Y.; Xiao, M.; Lu, Y. Direct synthesis of dimethyl carbonate (DMC) using Cu-Ni/VSO as catalyst. J. Mol. Catal. A Chem. 2006, 249, 93-97. [CrossRef]

20. LaMotte, J.; Saur, O.; LaValley, J.-C.; Busca, G.; Rossi, P.F.; Lorenzelli, V. Coadsorption of methanol and carbon dioxide on alumina. J. Chem. Soc. Faraday Trans. 1986, 82, 3019-3023. [CrossRef]

21. Tomishige, K.; Ikeda, Y.; Sakaihori, T.; Fujimoto, K. Catalytic properties and structure of zirconia catalysts for direct synthesis of dimethyl carbonate from methanol and carbon dioxide. J. Catal. 2000, 192, 355-362. [CrossRef]

22. Juan-Juan, J.; Roman-Marinez, M.C.; Illan-Gomez, M.J. Catalytic activity and characterization of $\mathrm{Ni}_{2} \mathrm{Al}_{2} \mathrm{O}_{3}$ and $\mathrm{NiK}_{2} \mathrm{Al}_{2} \mathrm{O}_{3}$ catalysts for $\mathrm{CO}_{2}$ methane reforming. Appl. Catal. A 2004, 264, 2, 169-174. [CrossRef]

23. Moh'd, T.K. Kinetics and Mechanism of Methanol Decomposition over Zinc Oxide. Ph.D. Thesis, Iowa State University, Ames, IA, USA, 1982.

24. Solymosi, F.; Tolmacsov, P.; Kedves, $\mathrm{K} . \mathrm{CO}_{2}$ reforming of propane over supported Rh. J. Catal. 2003, 216, 377-385. [CrossRef]

25. Wang, H.; Au, C. Carbon dioxide reforming of methane to syngas over SiO2-supported rhodium catalysts. Appl. Catal. A Gen. 1997, 155, 239-252. [CrossRef]

26. Liu, Y.-M.; Liu, J.T.; Liu, S.-Z.; Li, J.; Gao, Z.-H.; Zuo, Z.-J.; Huang, W. Reaction mechanisms of methanol synthesis from CO/CO 2 hydrogenation on $\mathrm{Cu}_{2} \mathrm{O}(111)$ : Comparison with $\mathrm{Cu}(111)$. J. $\mathrm{CO}_{2}$ Util. 2017, 20, 59-65. [CrossRef]

27. Grabow, L.C.; Mavrikakis, M. Mechanism of Methanol Synthesis on $\mathrm{Cu}$ through $\mathrm{CO}_{2}$ and $\mathrm{CO}$ hydrogenation. ACS Catal. 2011, 1 . [CrossRef]

28. Jung, K.T.; Bell, A.T. An in Situ Infrared Study of Dimethyl Carbonate Synthesis from Carbon Dioxide and Methanol over Zirconia. J. Catal. 2001, 204, 339-347. [CrossRef]

29. Wada, S.; Oka, K.; Watanabe, K.; Izumi, Y. Catalytic conversion of carbon dioxide into dimethyl carbonate using reduced copper-cerium oxide catalysts as low as $353 \mathrm{~K}$ and 1.3 MPa and the reaction mechanism. Front. Chem. 2013, 1, 1-8. [CrossRef]

30. Unnikrishnan, P.; Srinivas, D. Direct synthesis of dimethyl carbonate from $\mathrm{CO}_{2}$ and methanol over $\mathrm{CeO}_{2}$ catalysts of different morphologies. J. Chem. Sci. 2016, 128, 957-965.

31. Xie, S.; Bell, A.T. An in situ Raman study of dimethyl carbonate synthesis from carbon dioxide and methanol over zirconia. Catal. Lett. 2000, 70, 137-143. [CrossRef]

32. Jung, K.T.; Bell, A.T. Effects of Catalyst Phase Structure on the Elementary Processes Involved in the Synthesis of Dimethyl Carbonate from Methanol and Carbon Dioxide over Zirconia. Top. Catal. 2002, 20, 97-105. [CrossRef]

33. Somboon, C.; Oleg, V.S.; Jannes, D.; Wei, X.; Serge, Z.; Anish, K.; Francis, V. Progress on Catalyst Development for Direct Synthesis of Dimethyl Carbonate from $\mathrm{CO}_{2}$ and Methanol. Chem. Afr. 2019, 2, 533-549.

34. Beebe, T.P.; Crowell, J.E.; Yates, J.T. Reaction of methyl chloride with alumina surfaces: Study of the methoxy surface species by transmission infrared spectroscopy. J. Phys. Chem. 1988, 92, 1296-1301. [CrossRef] 